\title{
KEMAMPUAN GURU MOTIVASI SISWA SARANA DAN PRASARANA DALAM PEMBELAJARAN PENJASORKES KELAS IV DAN V DI SEKOLAH DASAR NEGERI 22 ANDALAS PADANG
}

\author{
Erizal $^{1}$, Emral $^{2}$, Suwirman $^{3}$ \\ ${ }^{1}$ Program Studi Pendidikan Jasmani Kesehatan dan Rekreasi, Fakultas Ilmu Keolahragaan, \\ Universitas Negeri Padang. Jalan Prof. Dr. Hamka Air Tawar Barat, Padang, 25132, Indonesia. \\ ${ }^{2}$ Program Studi Ilmu Keolahragaan, Fakultas Ilmu Keolahragaan, Universitas Negeri Padang. Jalan \\ Prof. Dr. Hamka Air Tawar Barat, Padang, 25132, Indonesia. \\ ${ }^{3}$ Program Studi Ilmu Keolahragaan, Fakultas Ilmu Keolahragaan, Universitas Negeri Padang. Jalan \\ Prof. Dr. Hamka Air Tawar Barat, Padang, 25132, Indonesia.
}

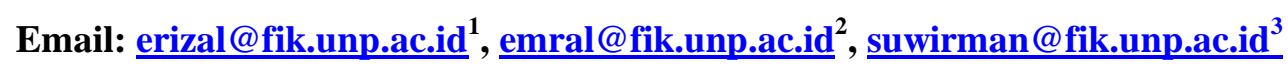

\begin{abstract}
Abstrak
Masalah dalam penelitian ini adalah belum optimalnya pelaksanaan pembelajaran penjasorkes di SD Negeri 22 Andalas Padang. Tujuan dari penelitian ini adalah untuk mengetahui kemampuan guru dalam pelaksanaan pembelajaran, motivasi siswa dan sarana prasarana di SD Negeri 22 Andalas Padang.

Penelitian ini menggunakan jenis penelitian deskriptif, yaitu mengungkap dan menerangkan pelaksanaan UKS di SD Negeri 22 Andalas Padang. Populasi dalam penelitian ini adalah seluruh siswa di SD Negeri 22 Andalas Padang yang berjumlah 57 orang. Teknik sampel yang digunakan yaitu total sampling yang berjumlah 57 orang. Alat pengumpulan data adalah angket dengan mengunakan model skala guttman dengan kategori jawaban 'ya' dan 'tidak'.. Selanjutnya data diolah dan dianalisis dengan teknik statistik deskriptif.

Hasil analisis data SD Negeri 22 Andalas Padang antara lain kemampuan guru dalam pelaksanaan pembelajaran Penjasorkes di peroleh tingkat capaian sebesar 70\% berada pada klasifikasi cukup. Motivasi siswa diperoleh tingkat capaian sebesar $73 \%$ berada pada klasifikasi cukup, sedangkan pada sarana dan prasarana diperoleh tingkat capaian sebesar $60 \%$ berada pada klasifikasi kurang baik.
\end{abstract}

Kata Kunci: Kemampuan Guru, Motivasi Siswa, Sarana dan Prasana, Pembelajaran Pendidikan Jasmani Kesehatan dan Rekreasi

\section{PENDAHULUAN}

Upaya pembangunan manusia Indonesia pada hakikatnya adalah salah satu upaya yang dilakukan secara sadar, berencana dan berkesinambungan menuju suatu perubahan dan kemajuan serta perbaikan yang sempurna. Dalam pelaksanaan pembangunan ini kita semua dituntut untuk selalu berusaha menambah, memperdalam serta meningkatkan kualitas dan kuantitas ilmu pengetahuan serta keterampilan, untuk itu sektor pendidikan memegang peranan penting dalams upaya pencapaian tujuan tersebut.

Dalam Undang-undang NO.20 Tahun 2003 dijelaskan bahwa tujuan Pendidikan Nasional adalah :

"Pendidikan Nasional berfungsi mengembangkan kemampuan dan membentuk watak serta peradaban bangsa yang bermatabat dalam rangka mencesdarkan kehidupan bangsa, bertujuan untuk berkembangnya potensi peserta didik agar menjadi manusia yang beriman dan beartaqwa kepada Tuhan Yang Maha Esa, berakhlak mulia, sehat beriman, cakap, kreatif, mandiri, dan menjadi warga negara yang demokratis secara bertanggung jawab "

Berdasarkan kutipan di atas jelaslah bagi kita bahwa pendidikan tersebut sangat mempunyai peranan penting untuk mewujudkan watak seseorang yang akhirnya menjadi cerdas, yang beriman dan bertaqwa kepada Tuhan Yang Maha Esa, berakhlak mulia, sehat jasmani dan rohani.

Pendidikan jasmani pada dasarnya merupakan bagian dari sistem pendidikan secara keseluruhan. Tujuan pendidikan jasmani bukan hanya mengembangkan ranah jasmani, tetapi 
juga mengembangkan aspek kesehatan, kebugaran jasmani, keterampilan berfikir kritis,stabilitas emosional, keterampilan sosial, penalaran dan tindakan moral melalui kegiatan aktivitas jasmani dan olahraga. Pendidikan jasmani merupakan media untuk mendorong perkembangan motorik, kemampuan fisik, pengetahuan dan penalaran, penghayatan nilainilai (sikap-mental-mosional-spritual-dan sosial), serta pembiasan pola hidup sehat yang bermuara untuk merangsang pertumbuhan dan perkembangan yang seimbang.

Sejalan dengan uraian diatas dalam Permendiknas No. 22 Tahun 2006 disebutkan bahwa untuk membantu siswa memantapkan kesegaran jasmani dan kesehatan melalui pengetahuan dan penanaman sikap positif serta kemampuan gerak dasar sebagai aktifitas jasmani antara lain :

“(1) Terbentuknya sikap dan prilaku seperti : disiplin, kejujuran, kerjasama mengikuti peraturan dan ketentuan yang berlaku;(2) Mempunyai kemampuan untuk menjelaskan tentang manfaat pendidikan jasmani dan kesehatan, serta mempunyai kemampuan, penampilan, keterampilan gerak yang benar dan efisien; (3) Meningkatkan kesegaran jasmani dan kesehatan serta daya tahan tubuh terhadap penyakit ".

Berdasarkan kutipan di atas, jelaslah bahwa pendidikan jasmani memiliki peran yang sangat penting dalam mengintensifkan penyelenggaraan pendidikan sebagai suatu proses pembinaan manusia yang berlangsung seumur hidup. Pendidikan jasmani memberikan kesempatan pada siswa untuk terlibat langsung dalam aneka pengalaman belajar melalui aktifitas jasmani, bermain dan berolahraga yang dilakukan secara sistematis, terarah dan terencana. Pembekalan pengalaman belajar itu diarahkan untuk membina, sekaligus membentuk gaya hidup sehat dan aktif sepanjang hayat.

Pelajaran pendidikan jasmani di sekolah bukan untuk mengejar prestasi (aspek skill) saja tetapi menyalurkan dorongan untuk aktif bermain. Pendidikan jasmani untuk anak sekolah dasar harus lebih menekankan kepada aspek permainan dari pada teknik cabang olahraganya karena bermain adalah kebutuhan yang harus dipenuhi oleh setiap anak pada usia sekolah dasar. Annario dalam Harsuki (2002 : 16) juga menjelaskan bahwa "pendidikan jasmani merupakan pendidikan lewat aktifitas jasmani yang telah ditetapkan dalam Undang-undang dan
Permen dalam lingkup fisik, psikomotor, efektif dan kognitif.

Berdasarkan pendapat di atas, maka untuk membentuk sikap, prilaku, disiplin dan kejujuran meningkatkan kesegaran jasmani dan kesehatan serta daya tahan penyakit, pendidikan jasmani olahraga dan kesehatan merupakan salah satu aspek yang dibutuhkan oleh peserta didik dalam mewujudkan tujuan pendidikan nasional.

Dalam intensifikasi penyelenggaran pendidikan sebagai suatu proses pembinaan manusia langsung seumur hidup, peranan Pendidikan Jasmani adalah sangat penting, yang memberikan kesempatan kepada siswa untuk terlibat langsung dalam aneka pengalaman belajar melalui aktivitas jasmani, bermain dan berolahraga yang dilakukan secara sistematis. Pembekalan pengalaman belajar itu diarahkan untuk membina, sekaligus membentuk gaya hidup sehat dan aktif sepanjang hayat.

Pendidikan jasmani sebenarnya bukan hanya merupakan aktivitas fisik secara terisolasi, akan tetapi harus ada dalam konteks pendidikan secara umum (general education). Tentunya proses tersebut dilakukan dengan sadar dan melibatkan interaksi sistematik antar pelakunya untuk mencapai tujuan yang ditetapkan.

Ditambah lagi dengan sistem penilaian kinerja guru dalam rangka kenaikan pangkat yang tidak dilakukan oleh orang yang mampu dibidangnya. Akibatnya, guru Penjasorkes tidak terpacu untuk terus mengembangkan karir profesionalnya. Guru Penjasorkes umumnya pasif dalam mengantisipasi pengembangan profesinya. Disamping itu kekurangan sarana prasarana pembelajaran Penjasorkes menjadi salah satu penyebab tidak terpacunya guru Penjasorkes untuk mengembangkan karir profesinya sesuai dengan kurikulum yang ada.

Dengan demikian agar pendidikan jasmani olahraga dan kesehatan mencapai hasil yang maksimal, maka dalam pelaksanaan pendidikan jasmani olahraga dan kesehatan di sekolah harus mengacu pada Permendiknas No. 22 Tahun 2006 tentang KTSP, sehingga diharapkan pelaksanaan Penjasorkes akan terlaksana sesuai dengan ditetapkan. Artinya guru Penjasorkes dituntut untuk mampu membuat perencanaan pembelajaran penjasorkes yang sesuai dengan kurikulum, mampu membuat RPP, mampu melaksanakan pembelajaran, dan mampu mengevaluasi hasil dari pelaksanaan pembelajaran.

Berdasarkan pengamatan penulis Di SD Negeri 22 Andalas Padang bahwa pembelajaran 
Penjasorkes belum berjalan sebagaimana mestinya, sehingga tingkat pencapaian hasil belajar siswa belum sepenuhnya mencapai angka 7 sebagai batas lulus minimal yang diharapkan. Kurang terlaksananya pembelajaran Penjasorkes tersebut diduga karena kurangnya kemampuan guru dalam merencanakan program pengajaran, keterbatasan sarana dan prasarana kurang tepatnya metode mengajar yang digunakan guru, kurangnya kemampuan guru melakukan modifikasi materi, lemahnya motivasi belajar siswa, serta kurangnya dukungan kepala sekolah. Memperhatikan masalah tersebut maka banyak faktor yang menyebabkan kurang terlaksananya di SD Negeri 22 Andalas Padang. bahwa: Zalfendi dkk (2010: 172-181) menyatakan

"pendidikan jasmani olahraga dan kesehatan merupakan bagian integral dari usaha pendidikan secara keseluruhan, bertujuan untuk mengembangkan aspek kebugaran jasmani, keterampilan gerak, keterampilan berfikir kritis, keterampilan sosial, penalaran stabilitas emosional, tindakan moral, aspek pola hidup sehat dan pengenalan lingkungan bersih melalui aktifitas jasmani, olahraga dan kesehatan terpilih yang direncanakan secara sistematis dalam rangka mencapai tujuan pendidikan nasional."

Pendidikan sebagai suatu proses pembinaan manusia yang berlangsung seumur hidup, pendidikan jasmani, olahraga dan kesehatan yang diajarkan disekolah memiliki peranan yang sangat penting, yaitu memberikan kesempatan kepada peserta didik untuk terlibat langsung dalam berbagai pengalaman belajar melalui aktivitas jasmani, olahraga dan kesehatan yang terpilih yang dilakukan secara sistematis. Pembekalan pengalaman belajar itu di arahkan untuk membina pertumbuhan fisik dan pengembangan psikis yang lebih baik, sekaligus membentuk pola hidup sehat dan bugar sepanjang hayat.

Pendidikan memiliki sasaran pedagogis, oleh karena itu pendidikan kurang lengkap jika tanpa pendidikan jasmani, olahraga dan kesehatan, karena gerak sebagai aktivitas jasmani adalah dasar bagi manusia untuk mengenal dunia dan dirinya sendiri yang secara alami berkembang searah dengan perkembangan zaman.

Selama ini telah terjadi kecendrungan dalam memberikan makna mutu pendidikan yang hanya dikaitkan dengan aspek kemampuan koqnitif. Pandangan ini telah membawa akibat terabainya aspek-aspek moral, akhlak, budi pekerti, seni, psikomotor, serta life skill. Dengan diterbitkannya Undang-Undang Nomor 20 Tahun 2003 tentang sistem pendidikan nasional dan peraturan pemerintah Nomor 19 Tahun 2005 Tentang Standar Nasional Pendidikan akan memberikan peluang untuk menyempurnakan kurikulum yang komprehensif dalam rangka mencapai tujuan pendidkan nasional.

Pendidikan jasmani, olahraga dan kesehatan merupakan media untuk mendorong pertumbuhan fisik, perkembangan psikis, ketrampilan motorik, pengetahuan dan penalaran, penghayatan nilai-nilai (sikap-mental-emosionalsportivitas-spritual-sosial), serta pembinaan pola hidup sehat yang bermuara untuk merangasang pertumbuhan dan perkembangan kualitas fisik dan psikis yang seimbang. kesehatan

Tujuan Pendidikan Jasmani olahraga dan

a. Mengembangkan keterampilan pengelolaan diri dalam upaya pengembangan dan pemeliharaan kebugaran jasmani serta pola hidup sehat melalui berbagai aktifitas jasmani dan olahraga yang terpilih.

b. Meningkatkan pertumbuhan fisik dan pengembangan psikis yang lebih baik.

c. Meningkatkan kemampuan dan keterampilan gerak dasar.

d. Memahami konsep aktifitas jasmani dan olahraga di lingkungan yang bersih sebagai informasi untuk mencapai pertumbuhan fisik yang sempurna, pola hidup sehat dan kebugaran terampil, serta memiliki sikap yang positif.

e. Membantu siswa untuk perbaikan derajat kesehatan dan kesegaran jasmani melalui pengertian pengembangan sikap positif dan keterampilan gerak dasar.

f. Pendidikan jasmani mempunyai kepuasan intelektual dan dapat melaksanakan apresiasi keindahan. Dalam pendidikan jasmani terdapat peraturan-peraturan, strategi-strategi, teknik-teknik, prinsip-prinsip kinesosiologi, sejarah olahraga, arti kebudayaan olahraga, dan peraturanperatuaran latihan yang dapat dipelajari.

\section{Kemampuan Guru Dalam Pembelajaran Penjasorkes}


Salah satu faktor yang berperan dalam proses pembelajaran penjasorkes adalah guru atau pendidik, karena pendidik sebagai manager yang mengelola kelas diharapkan mampu untuk dapat membangun motivasi peserta didik terhadap materi yang diajarkannya. Dengan terciptanya situasi kelas yang termotivasi akan dapat mempengaruhi proses belajar serta tingkah laku peserta didik.

Hal ini seiring denagn pendapat Yelon dan Grace seperti yang dikutip oleh Prayitno (1989 : 4) bahwa :"Peningkatan motivasi sisiwa dalam belajar merupakan suatu acara yang baik dalam menghindari tingkah laku siswa yang menyimpang, yaitu dengan cara melibatkan mereka dalam belajar dan merangsang mereka untuk belajar".

Lutan (2001 : 52) menyatakan bahwa ada

"beberapa azas yang harus diperhatikan oleh guru Penjasorkes dalam mengajar, yaitu: (a) azas pendidikan menyeluruh, (b) azas perumusan tujuan yang realistik, (c) azas individualistik dalam penjas, (d) azas mengutamakan kesenangan, (e) azas pertisipasi merata dan menyeluruh, (f) azas mengutamakan pengalaman sukses".

Azas pendidikan bersifat menyeluruh dalam artian bahwa Penjasorkes tidak hanya mengembangkan keterampilan dan kesegaran jasmani tetapi juga mengembangkan aspek lain seperti kognitif dan afeksi. Dalam perumusan tujuan hendaknya guru Penjasorkes merumuskan tujuan secara lengkap di dalam (lesson plan) baik kognisi, afeksi, psikomotor dan sosialnya. Dengan perumusan tujuan yang lengkap tergambar dalam kegiatan belajar mengajar tentu siswa akan mendapatkan domain yang ingin dicapai dalam pembelajaran.

Azas perumusan tujuan yang realistik diartikan bahwa dalam perumusan tujuan guru harus memperhatikan karekteristik pertumbuhan dan perkembangan siswa. Dalam perumusan tujuan pembelajaran guru harus memperhatikan siswa (audience), tingkah laku (behavior), kondisi (condition), dan tingkatan (degree). Dalam menetapkan tujuan pembelajaran yang pertama pertanyaan yang diajukan guru, yaitu siswa kelas berapa yang akan diajar? Kedua, bagaimana kondisi yang ada? Ketiga, tingkatan pencapaian tujuan misalnya siswa dapat melompat ke samping kiri, kanan, muka, belakang dengan baik.

Azas individualisme dalam Penjasorkes dalam artian siswa merupakan individu yang memiliki ciri-ciri tersendiri seperti potensi, tempo belajar, kelemahan dan keunggulan. Oleh sebab itu kemajuan belajar anak juga bersifat perorangan. Untuk itu dalam kegiatan pembelajaran guru harus memperhatikan individu masing-masing siswa misalnya dalam lompat tali. Tali dipasang miring agar siswa dalam melompat secara keseluruhan sesuai dengan kemampuan melompatnya. Begitu juga dengan penelitian kemajuan belajar siswa harus dapat menggambarkan kemajuan individu.

Azas mengutamakan kesenangan dan kebebasan bergerak diartikan sebagai pembelajaran yang berorientasi pada siswa. Dalam hal ini dituntut guru untuk merencanakan pembelajaran yang menciptakan kesenangan seperti penerapan modifikasi olahraga ke dalam penjasorkes yang orientasi pembelajarannya pada aktifitas belajar (learning activities) dan kesenangan (gymfun) dengan pendekatan bermain dan kompetisi. Dengan bermain dan kompetisi membangkitkan rasa senang dan semangat kompetisi.

Azas partisipasi merata dan menyeluruh dalam artian pembelajaran penjas harus melibatkan seluruh siswa tanpa memandang jenis kelamin. Untuk guru harus merancang permainan yang dapat membangkitkan semangat siswa, sehingga kegiatan yang dilakukan tidak terkesan untuk satu jenis kelamin saja. Penciptaan pembelajaran melalui stasion-stasion lebih memberikan kesempatan kepada masing-masing kelompok untuk melakukan tugasnya masingmasing. Partisipasi siswa dalam melakukan Penjasorkes dapat diukur dari aktivitas yang dilakukan siswa 50 persen dari waktu yang tersedia dengan aktivitas gerak.

Azas mengutamakan pengalaman sukses dalam artian memberikan kesempatan kepada siswa untuk melakukan tugas Penjasorkes sebanyak mungkin. Dengan pengalaman gerak yang banyak tentu siswa dapat merasakan gerakan yang dilakukannya. Pemberian pujian (rewards) diperlukan pada saat siswa melakukan suatu gerakan. Dengan pujian tentu siswa mengulangi keberhasilan yang telah dilakukan.

Untuk itu, guru Penjasorkes harus selalu menggunakan pertahapan pembelajaran dari yang mudah ke yang sukar, dari gerakan yang sedikit yang komplesk. Dengan kondisi bertahap siswa mendapatkan pengalaman yang sukses pada masing-masing pertahapan pembelajaran. Dengan pengalaman sukses membentuk sikap positif siswa dalam melakukan Penjasorkes baik di sekolah maupun di rumah sebagai pengisi waktu luang. 


\section{Motivasi Siswa Terhadap Pembelajaran Penjasorkes}

Motivasi merupakan suatu energi penggerak, pengarah dan memperkuat tingkah laku. Witherington (1986 : 37) menegaskan pula bahwa "motivasi merupakan struktur dari berbagai motif-motif atau faktor penggerak yang menyebabkan timbulnya perilaku tertentu pada diri seseorang".

Sarwono (1983 : 57) mengartikan motivasi sebagai "keseluruhan proses perbuatan tingkah laku manusia, termasuk situasi yang mendorong, dorongan yang timbul dalam diri individu, tingkah laku yang ditimbulkan oleh situasi dan tujuan atau akhir dari perbuatan tersebut".

Selanjutnya Whitaker dalam Soemanto (1990 : 193) memberikan motivasi sebagai "Kondisi-kondisi atau keadaan yang mengaktifkan atau memberi dorongan kepada makhluk untuk bertingkah laku mencapai tujuan yang ditimbulkan oleh motivasi tersebut". Kemudian Winkell (1984 : 7) menyatakan bahwa motivasi merupakan "Daya penggerak dari dalam dan di dalam subjek untuk melakukan aktivitas-aktivitas tertentu demi mencapai suatu tujuan yang telah menjadi aktif'.

Dengan memperhatikan beberapa pendapat yang berkenaan dengan definisi motivasi, maka dapat disimpulkan bahwa motivasi merupakan dorongan dan rangsangan yang terjadi di dalam diri individu yang diwujudkan kepada tingkah laku untuk memenuhi kebutuhan yang diinginkan. Dengan terwujudnya motivasi ke dalam bentuk tingkah laku, maka dapat diketahui dan diramalkan apa yang menjadi tujuan individu.

a. Motivasi instrinsik

Motivasi instrinsik merupakan "motifmotif yang berfungsi bukan diakibatkan pengaruh rangsangan dari luar" (Suryabrata, 1984 : 28) sedangkan Purwanto (1990 : 65) disebut motivasi instrinsik "jika yang mendorong individu untuk bertindak adalah nilai-nilai yang terkandung di dalam objek itu sendiri”. Sedangkan Winkel (1984: 28) mendefinisikan "sebagai bentuk motivasi yang di dalamnya aktivitas belajar dimulai dan diteruskan berdasarkan suatu dorongan yang secara mutlak berkaitan dengan motivasi belajar".

Seorang individu dalam memperhatikan tingkah lakunya tidak hanya dipengaruhi oleh faktor lingkungan. Tetapi karena adanya energi yang berasal dari dalam diri individu itu sendiri. Kegiatan-kegiatan yang ditunjukkan oleh tingkah lakunya merupakan kehendaknya sendiri untuk mencapai tuujuan yang diinginkan.

Timbulnya motivasi instrinsik dalam proses belajar pada seorang peserta didik dapat diperhatikan dari sikap dan tingkah lakunya dalam mengikuti suatu kegiatan atau proses (Soemanto, 1990 : 190). Misalnya memperlihatkan tingkah laku yang tekun dalam mengikuti dan mengerjakan segala tuga-tugas yang dibebankan kepadanya.

Dengan termotivasinya siswa dalam proses belajar mengajar, bila dilaksanakan secara kontinu akan menumbuhkan kemauan dan kerja keras pada diri peserta didik. Sehingga apabila disalurkan secara baik dapat dihubungkan dengan tujuannya untuk berprestasi. Memperhatikan pengaruh yang diakibatkan dengan adanya motivasi instrinsik menimbulkan kesan kiranya faktor ini dapat terus dikembangkan dalam usaha menumbuh dan mengembangkan motif peserta didik sesuai dengan potensi yang dimilikinya.

Menurut Yusuf (1987 : 83), "Motifasi instrinsik merupakan sumber tenaga yang paling tahan lama, karena peserta didik merasa senang dan puas dalam belajar. Sehingga dalam pengelolaan proses belajar mengajar pendidik hendaknya dapat memperhatikan faktor-faktor yang tumbuh dari motivasi instrinsik seperti yang dimaksud dari pendapat tersebut".

Indikator-indikator yang termasuk dalam motivasi belajar yang berasal dari faktor psikis atau dalam diri. Menurut pendapat Anderson dan Faust seperti yang dikutip oleh Prayitno (1989 : 10) mengemukakan: adalah minat, ketajaman perhatian, konsentrasi, dan ketekunan. Sedangkan Winkel (1984 : 43) mengemukakan:” sikap, perasaan, minat dan kondisi akibat keadaan kultural/ekonomis".

Dengan memperhatikan beberapa pendapat tersebut di atas, maka dapatlah disimpulkan bahwa indikator motivasi instrinsik adalah sikap, perasaan, minat, bakat, kebutuhan kesehatan, perhatian, kondisi siswa. Dalam pembehasan selanjutnya dijelaskan indikatorindikator yang diuraikan di atas.

b. Motivasi ekstrinsik

Motivasi ekstrinsik menurut Prayitno (1989 : 13) adalah “ Motivasi yang keberadaannya bukan merupakan perasaan atau keinginan yang ada dalam dirinya". Winkel (1984 : 27), yang dimaksud motivasi ekstrinsik adalah bentuk motivasi yang di dalamnya aktivitas belajar dimulai dan diteruskan 
berdasarkan suatu dorongan yang tidak secara mutlak berkaitan dengan aktivitas belajar.

Dengan demikian timbulnya motivasi ekstrinsik tidak dilandasi oleh kondisi yang ada di dalam diri siswa, melainkan keberadaannya akibat ransangan dari faktor luar, sehingga tujuan yang hendak dicapai dari aktivitas tersebut berada di luar proses. Menurut penelitian Lother seperti yang ditulis Prayitno (1989 : 14), banyak sekali siswa yang dorongan belajarnya adalah motivasi ekstrinsik. Mereka memerlukan perhatian dan pengarahan serta dorongan yang khusus dari guru.

Dengan adanya motivasi ekstrinsik akan menggerakkan dan mendorong peserta didik dalam mencari tujuan yang telah ditetapkan. Semakin tinggi makna yang hendak dicapai, akan berpengaruh terhadap kuatnya tingkat motivasi yang akan di timbulkan.

Seorang pendidik dalam usaha membangunkan tingkat motivasi peserta didiknya secara efektif, yang dilakukan adalah dengan mempelajari kebutuhannya secara individual sehingga dapat menggunakan strategi pengajaran yang sesuai dengan kebutuhan peserta didiknya. Dengan demikian seorang pendidik dapat mempergunakan suatu strategi pengajaran yang sesuai dengan kebutuhan peserta didiknya.

Peserta didik yang termotivasi secara ekstrinsik pada hakekatnya memandang proses belajar mengajar hanyalah sebagai sarana atau alat dalam mencapai tujuannya. Sehingga tingkah laku uang biasanya diperhatikan menganggap belajar bukan hal yang mutlak dapat mempengaruhi tujuan yang ingin dicapainya (Winkel, $1984: 28$ ).

Bertitik tolak dari pendapat beberapa ahli tersebut ternyata banyak memiliki kesamaan. Karena itu dapat disimpulkan indikator motivasi ekstrinsik atas pujian, pemberitahuan kemajuan belajar, hadiah, hukuman, penghargaan dan persaingan.

\section{Sarana dan Prasarana}

Saranan dan prasarana salah satu faktor dalam proses belajar mengajar untuk mencapai tujuan, serta mempengaruhi timbulnya motivasi siswa dalam belajar pendidikan jasmani, dengan lengkapanya sarana dan prasarana olahraga disekolah tidak hanya siswa saja yang akan termotivasi untuk belajar, guru yang mengajar pun lebih semangat dan termotivasi untuk mengajar karena sarana dan prasarana yang lengkap ada di sekolah.
Menurut Yanis (1989 : 20) Sarana dan prasarana adalah kedudukan sarana dan prasarana dalam pendidikan pada umumnya, khususnya pendidikan olahraga memegang peranan penting, sarana dan prasarana tersebut harus disediakan sesuai dengan kebutuhan di lapangan. Sarana dan prasarana yang memadai menunjang berjalannya proses belajar mengajar secara efektif dan efisien, tanpa di dukung oleh sarana dan prasarana yang memadai untuk sukar diramalkan pencapaian tujuan yang diharapkan.

Di dalam Undang-undang RI No. 3 Tahun 2005 tentang Sistem Keolahragaan Nasional (SKN) dijelaskan pengertian "Sarana olahraga adalah peralatan dan perlengkapan yang digunakan untuk kegiatan olahraga". Adapun peralatan lain yang menjelaskan pengertian sarana adalah segala sesuatu yang dapat dipakai sebagai alat dalam pencapaian maksud atau tujuan, (Depdikbud, 1989 : 784).

Dari beberapa kutipan di atas dapat ditarik kesimpulan bahwa sarana olahraga adalah suatu hal yang mempunyai peranan yang sangat penting, terutama untuk kelancaran kegiatan olahraga. Tanpa dukungan oleh sarana yang memadai maka kegiatan olahraga sulit untuk terlaksana sesuai dengan apa yang kita harapkan.

Sarana olahraga sangat diperlukan dan harus ada pada saat mau melakukan olahraga tidak terlaksana dengan baik. Dengan demikian olahraga merupakan salah satu faktor yang harus diperhatikan agar pembelajaran pendidikan jasmani dapat berjalan dengan lancar sesuai dengan yang diharapkan.

Sarana dan prasarana alat belajar mengajar pendidikan jasmani dan kesehatan merupakan media yang sering dugunakan dalam proses pembelajaran pendidikan jasmani. Pengenalan tentang fungsi dan kemampuan sarana ini sangat penting artinya bila sarana merupakan bagian integral dari sistem pembelajaran pendidikan jasmani karena dasar kebijakan dalam pemilihan, pengembangan, maupun pemanfaatan sarana pendidikan tidak terlepas dari pengetahuan.

Kemudian sarana dan prasarana olahraga adalah segala sesuatu yang menunjang pencapaian dalam memberikan pengetahuan kepada siswa tentang olahraga, yang sengaja dipersiapkan oleh guru mata pelajaran dan seseorang yang sedang belajar atau sedang membelajarkan. Sarana dan prasarana dapat membentuk gedung,lapangan, alat olahraga dan media lainnya. 


\section{METODE}

Jenis penelitian yang digunakan adalah deskriptif yaitu meninjau dan mendeskripsikan suatu keadaan pada saat penelitian dilakukan. Menurut Sudjana (1989:64) Penelitian deskriptif adalah "Penelitian yang berusaha mendeskripsikan suatu gejala-gejala, peristiwa, kejadian yang terjadi pada saat sekarang". Hal ini juga diperkuat oleh pendapat Lufri (1999:54) "Penelitian deskriptif adalah penelitian yang mendeskripsikan atau memusatkan perhatian kepada masalah aktual yang sedang atau sudah terjadi dan data yang dilengkapkan apa adanya tanpa manipulasi”.

Populasi dalam penelitian ini adalah seluruh perwakilan siswa kelas di 22 Andalas Padang yang diambil dari kelas IV V, yang berjumlah 57 Orang. Untuk lebih jelasnya dapat dilihat pada tabel berikut:

\section{Tabel.1}

Populasi siswa SDN 22 Andalas Padang

\begin{tabular}{|c|c|c|c|c|}
\hline No & Kelas & putra & putri & Jumlah \\
\hline 1 & Kelas IV & 14 & 15 & 29 \\
\hline 2 & Kelas V & 12 & 16 & 28 \\
\hline Total & 26 & 31 & 57 & \multicolumn{1}{|c}{} \\
\cline { 1 - 3 } & \multicolumn{2}{|c|}{} & &
\end{tabular}

Sumber data : Tata usaha SDN 22 Andalas Padang

Setelah dihitung ternyata total populasi 148, berdasarkan keterbatasan penulis dalam penelitian maka penelitian akan menggunakan penarikan sampel secara sederhana diartikan sebagai bagian dari populasi yang terjadi sumber data yang sebenarnya dalam suatu penelitian.

Menurut Arikunto (1992:34) "apabila penarikan sampel kurang dari 100 orang maka dapat digunakan teknik penarikan sampel dengan teknik total sampling, dengan demikian peneliti menarik total sampel dari kelas IV dan V SDN 22 Andalas Padang yang berjumlah 57 orang. Untuk lebih jelasnya dapat dilihat pada tabel berikut ini:

Tabel.1

Populasi siswa SDN 22 Andalas Padang

\begin{tabular}{|c|c|c|c|c|}
\hline No & Kelas & putra & putri & Jumlah \\
\hline 4 & $\begin{array}{c}\text { Kelas } \\
\text { IV }\end{array}$ & 14 & 15 & 29 \\
\hline 5 & $\begin{array}{c}\text { Kelas } \\
\text { V }\end{array}$ & 12 & 16 & 28 \\
\hline \multicolumn{2}{|c|}{ Total } & 26 & 31 & 57 \\
\hline
\end{tabular}

Terdapat dua jenis data yang akan diambil pada penelitian ini, yaitu:

a. Data primer, yaitu data tentang Pembelajaran Penjasorkes di SD Negeri 22 Andalas Padang

b. Data sekunder, yaitu data tentang jumlah siswa
Sesuai dengan judul dalam penelitian ini maka yang menjadi sumber data dalam penelitian ini adaah guru, siswa dan kepala sekolah SD Negeri 22 Andalas Padang.

\section{A. Instrument Penelitian}

Alat yang digunakan untuk mengumpulkan data pada penelitian ini yaitu kuesioner (angket). Kuesioner ini digunakan untuk memperoleh data tentang modifikasi. Kuesioner ini di isi oleh siswa yang terpilih menjadi responden yang bertujuan untuk mendapatkan data atau informasi sehubungan dengan kemampuan guru,motivasi siswa dan sarana prasarana dalam pembelajaran penjasorkes di SD Negeri 22 Andalas Padang.

Pengumpulan data dengan angket yaitu suatu cara pengumpulan data dengan menyusun daftar pertanyaan yang diberikan kepada orang lain untuk bersedia memberikan respon sesuai permintaan. Ridwan (2003 : 12) menjelaskan bahwa angket sebagai alat utama mengumpulkan data di susun dengan menggunakan skala quipmen dalam penyusunan angket dilakukan beberapa tahap, yaitu penentuan indikator, kisikisi dan angket. Setiap butir pertanyaan disediakan 2 pilihan jawaban yaitu: "ya" dan "tidak", dimana responden menjawab ya pada item diberi skor 1, sebaliknya bagi responden yang menjawab tidak pada item akan diberi skor 0 .

Kisi-kisi instrumen penelitian

\begin{tabular}{|c|c|c|c|c|}
\hline No & Variabel & Indikato & & Item pertanyaan \\
\hline 1 & $\begin{array}{l}\text { Kemam } \\
\text { puan } \\
\text { guru }\end{array}$ & 1. & $\begin{array}{l}\text { Pelaksan } \\
\text { aan } \\
\text { pembelaj } \\
\text { aran } \\
\text { penjasor } \\
\text { kes } \\
\text { Dalam } \\
\text { memberi } \\
\text { kan } \\
\text { materi } \\
\text { pembelaj } \\
\text { aran dan } \\
\text { modifika } \\
\text { si } \\
\text { permaina } \\
\text { n }\end{array}$ & $\begin{array}{l}2,3,4,6.9 \\
1,5,7,8,10\end{array}$ \\
\hline 2 & $\begin{array}{l}\text { Motivas } \\
\text { i siswa }\end{array}$ & $\begin{array}{l}1 . \\
2 .\end{array}$ & $\begin{array}{l}\text { Motivasi } \\
\text { instrinsik } \\
\text { Motivasi } \\
\text { ekstrinsi } \\
\mathrm{k}\end{array}$ & $\begin{array}{l}11,13,14,15,16, \\
17 \\
12,18,19,20\end{array}$ \\
\hline 3 & $\begin{array}{l}\text { Sarana } \\
\text { dan } \\
\text { prasaran } \\
\text { a }\end{array}$ & 1. & $\begin{array}{l}\text { Kelengka } \\
\text { pan } \\
\text { sarana } \\
\text { dan } \\
\text { prasarana } \\
\text { Pemeriks } \\
\text { aan, } \\
\end{array}$ & $\begin{array}{l}21,24,25,26,27, \\
28,29,30 \\
22,23\end{array}$ \\
\hline
\end{tabular}




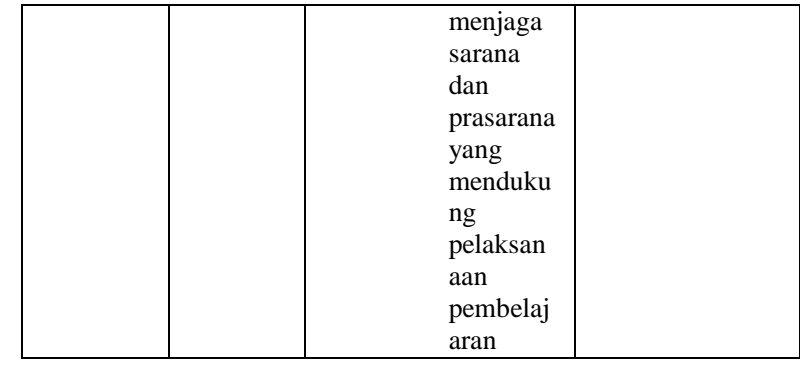

Teknik analisis data yang dilakukan dengan menggunakan statistic deskriptif yang menggunakan persentase jawaban. Klasifikasi nilai yang dicapai oleh responden menggunakan klasifikasi menurut Sudjana (1989:155) dengan pengkategorian sebagai berikut:

$\begin{array}{ll}90 \%-100 \% & \text { Sangat Baik } \\ 80 \%-89 \% & \text { Baik } \\ 65 \%-79 \% & \text { Cukup } \\ 55 \%-64 \% & \text { Kurang Baik } \\ 0 \%-54 \% & \text { Tidak Baik }\end{array}$

\section{HASIL DAN PEMBAHASAN}

Pada bagian ini akan diuraikan mengenai hasil penelitian. Hasil penelitian dan pengolahan data yang diuraikan dengan menggunakan analisis deskriptif, yang bertujuan untuk memberikan gambaran umum pembelajaran penjasorkes, yang terdiri dari : kemampuan guru, motivasi siswa dan sarana prasarana.

\section{A. Hasil Penelitian}

\section{Deskripsi Kemampuan Guru}

Menunjukan tentang Pembelajaran Penjasorkes diperoleh 40 orang (70\%) responden ya, sedangkan 17 orang $(30 \%)$ responden memilih jawaban tidak. Ini berarti pada umumnya siswa menilai pelaksanaan pembelajaran Penjasorkes dalam proses belajar mengajar Penjasorkes masih dalam kategori cukup. Dengan demikian artinya bahwa pembelajaran Penjasorkes di SD Negeri 22 Andalas Padang sudah cukup baik, namun masih perlu ditingkatkan sehingga pembelajaran Penjasorkes dapat berjalan dengan lebih baik.

Tabel 4 berikut memperlihatkan Deskripsi Kemampuan Guru Penjasorkes dalam pembelajaran Penjasorkes di SD Negeri 22 Andalas Padang.

\section{Tabel 4.}

Deskripsi Kemampuan Guru

\begin{tabular}{|c|c|c|c|c|}
\hline $\begin{array}{c}\text { N } \\
\text { o }\end{array}$ & $\begin{array}{c}\text { Kateg } \\
\text { ori }\end{array}$ & $\begin{array}{c}\text { Jumlah } \\
\text { Respond } \\
\text { en }\end{array}$ & $\begin{array}{c}\text { Persenta } \\
\text { se (\%) }\end{array}$ & $\begin{array}{c}\text { Tingkat } \\
\text { Capaian } \\
\%\end{array}$ \\
\hline 1 & Ya & 40 & 70 & 70 \\
\hline 2 & Tidak & 17 & 30 & \\
\hline & & 57 & 100 & \\
\hline
\end{tabular}

Pada Gambar 2 di bawah ini diperlihatkan secara keseluruhan grafik diagram batang kemampuan guru di SD Negeri 22 Andalas Padang

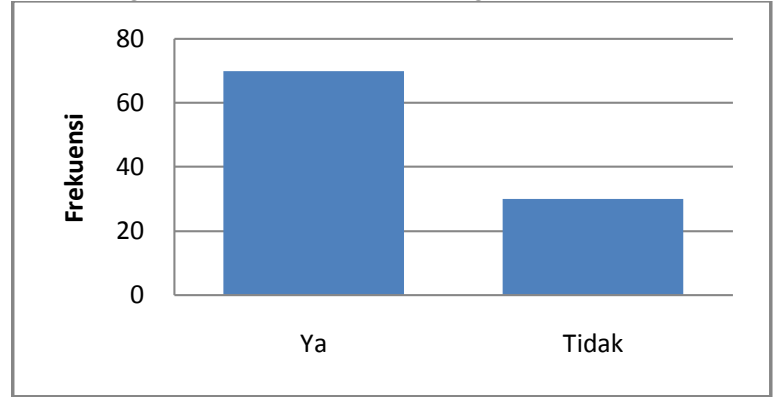

Gambar 2. Diagram Batang Distribusi Skor Kemampuan Guru

\section{Motivasi Siswa}

menunjukkan bahwa motivasi siswa dalam pembelajaran Penjasorkes, diperoleh 42 orang $(73 \%)$ responden memilih jawaban ya, dan 15 orang $(27 \%)$ responden memilih jawaban 
tidak. Ini berarti pada umumnya siswa menilai motivasi instrinsik dalam proses belajar mengajar Penjasorkes masih dalam kategori cukup. Dengan demikian artinya bahwa Pembelajaran Penjas di SD Negeri 22 Andalas Padang sudah cukup, namun masih perlu ditingkatkan sehingga pembelajaran penjasorkes dapat berjalan dengan lebih baik.

Tabel 6 berikut memperlihatkan Deskripsi Motivasi siswa dalam pembelajaran Penjasorkes di SD Negeri 22 Andalas Padang

Tabel 6.

Deskripsi Motivasi Siswa

\begin{tabular}{|c|c|c|c|c|}
\hline $\begin{array}{c}\text { N } \\
\text { o }\end{array}$ & $\begin{array}{c}\text { Katego } \\
\text { ri }\end{array}$ & $\begin{array}{c}\text { Jumlah } \\
\text { Respond } \\
\text { en }\end{array}$ & $\begin{array}{c}\text { Persenta } \\
\text { se } \\
(\%)\end{array}$ & $\begin{array}{c}\text { Tingk } \\
\text { at } \\
\text { Capaia } \\
\text { n } \\
(\%)\end{array}$ \\
\hline 1 & Ya & 42 & 73 & 73 \\
\cline { 1 - 3 } 2 & Tidak & 15 & 27 & \\
\hline & & 57 & 100 & \\
\hline
\end{tabular}

Pada gambar 3 di bawah ini diperlihatkan secara keseluruhan grafik Diagram Batang Motivasi Siswa di SD Negeri 22 Andalas Padang

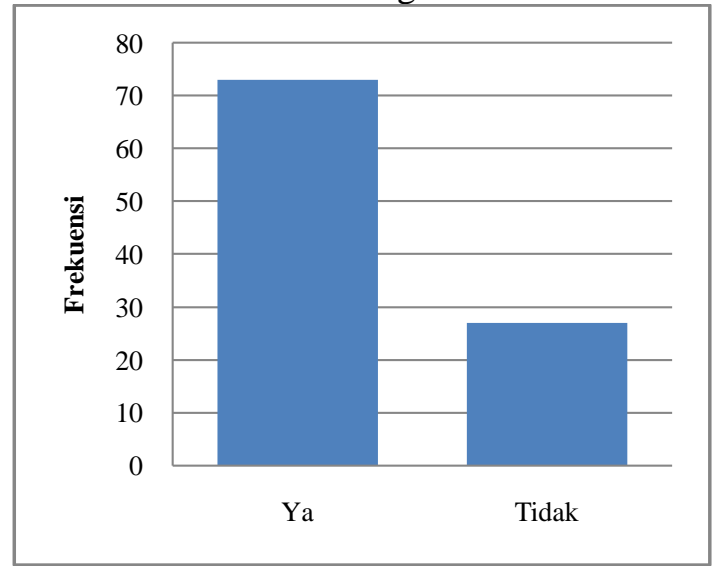

Gambar 3. Diagram Batang Distribusi Skor Motivasi Siswa

\section{Deskripsi Sarana dan Prasana}

Pada tabel 7 di atas menunjukkan bahwa kelengkapan sarana dan prasarana dalam pembelajaran Penjasorkes, diperoleh 34 orang $(60 \%)$ responden memilih jawaban ya, dan 23 orang $(40 \%)$ responden memilih jawaban tidak. Ini berarti pada umumnya sarana dan prasarana dalam proses belajar mengajar Penjasorkes masih dalam kategori kurang baik. Dengan demikian artinya bahwa sarana dan prasarana Pembelajaran Penjasorkes di SD Negeri 22 Andalas Padang kurang baik, namun masih perlu ditingkatkan sehingga pembelajaran Penjasorkes dapat berjalan dengan lebih baik di masa yang akan datang.
Tabel 8 berikut memperlihatkan deskripsi sarana dan prasarana dalam pembelajaran Penjasorkes di SD Negeri 22 Andalas Padang

\section{Tabel 8}

Deskripsi Sarana dan Prasarana

\begin{tabular}{|c|c|c|c|c|}
\hline $\begin{array}{c}\text { N } \\
\text { o }\end{array}$ & $\begin{array}{c}\text { Katego } \\
\text { ri }\end{array}$ & $\begin{array}{c}\text { Jumlah } \\
\text { Responde } \\
\mathrm{n}\end{array}$ & $\begin{array}{c}\text { Persentas } \\
\mathrm{e}(\%)\end{array}$ & $\begin{array}{c}\text { Tingka } \\
\mathrm{t} \\
\text { Capaia } \\
\mathrm{n}(\%)\end{array}$ \\
\hline 1 & Ya & 34 & 60 & 60 \\
\hline 2 & Tidak & 23 & 40 & \\
\hline & & 57 & 100 & \\
\hline
\end{tabular}

Pada gambar 4 di bawah ini diperlihatkan secara keseluruhan grafik Diagram Batang Sarana dan Prasarana di SD Negeri 22 Andalas Padang Sebagai berikut :

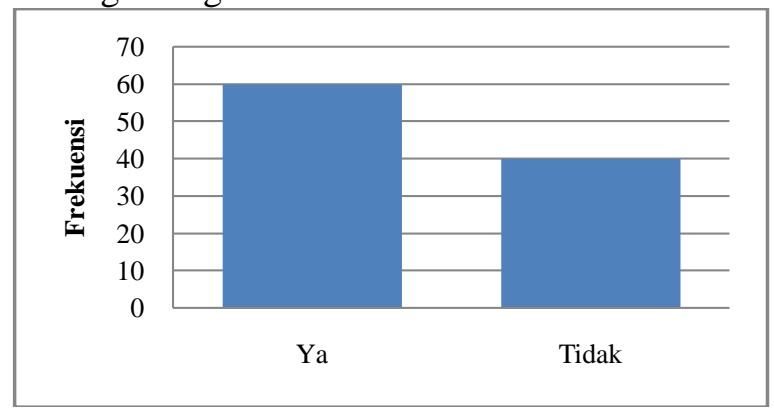

Gambar 4. Diagram Batang Distribusi Skor Sarana dan Prasarana

\section{Pembahasan}

Berdasarkan data hasil belajar penelitian yang telah diuraikan di atas,pengetahuan guru,motivasi siswa dan sarana prasarana terhadap pembelajaran Penjasorkes di SD Negeri 22 Andalas Padang, faktor-faktor tersebut seharusnya saling mendukung dan tersedia agar pelaksanaan di SD Negeri 22 Andalas Padang terlaksana dengan baik sesuai dengan yang diharapkan.

\section{Kemampuan Guru Terhadap Pembelajaran Penjasorkes Di SD Negeri 22 Andalas Padang. \\ Dalam proses belajar mengajar tidak} terkecuali proses belajar mengajar Penjasorkes guru memegang peranan penting, karena ini merupakan serangkaian kegiatan guru dan siswa atas dasar hubungan timbal balik (interaksi), dimana peristiwa ini berlangsung dalam situasi edukatif untuk mencapai tujuan pendidikan jasmani.

Berdasarkan hasil penelitian kemampuan terhadap Pembelajaran Penjasorkes di SD Negeri 22 Andalas Padang diperoleh tingkatan capaian sebesar $70 \%$. Berada pada klarifikasi cukup. Dengan demikian artinya bahwa pengetahuan guru Penjasorkes di SD Negeri 22 Andalas Padang. Pembelajaran Penjasorkes sudah cukup 
baik, namun masih perlu ditingkatkan sehingga dalam pembelajaran Penjasorkes dapat berjalan dengan baik.Untuk itu, guru penjasorkes harus selalu menggunakan pentahapan pembelajaran dari yang mudah ke yang sukar, dari gerakan yang sedikit yang kompleks. Dengan kondisi bertahap siswa mendapatkan pengalaman yang sukses membentuk sikap positif siswa dalam melakukan penjasorkes baik di sekolah maupun di rumah sebagai pengisi waktu luang.

2. Motivasi siswa Terhadap Pembelajaran Penjasorkes Di SD Negeri 22 Andalas Padang

Motivasi merupakan suatu energi penggerak, pengarah dan memperkuat tingkah laku. Motivasi juga merupakan struktur dari berbagai motif-motif atau faktor penggerak yang menyebabkan timbulnya perilaku tertentu pada diri seseorang. Berdasarkan hasil penelitian motivasi siswa terhadap pembelajaran Penjasorkes di SD Negeri 22 Andalas Padang diperoleh tingkatan capaian sebesar $73 \%$. Berada pada klarifikasi cukup. Dengan demikian artinya bahwa motivasi siswa terhadap pembelajaran Penjasorkes di SD Negeri 22 Andalas Padang sudah cukup baik, namun masih perlu ditingkatkan sehingga dalam pembelajaran penjasorkes dapat berjalan dengan baik. Untuk itu, guru Penjasorkes harus selalu memotivasi siswa agar pembelajaran Penjasorkes menjadi tambah lebih baik lagi.

Timbulnya motivasi dalam diri siswa dalam proses belajar mengajar dapat diperhatikan dari sikap dan tingkah lakunya dalam mengikuti suatu kegiatan atau proses (Soemanto, 1990 : 190). Misalnya memperlihatkan tingkah laku yang tekun dalam mengikuti dan mengerjakan segala tugas-tugas yang dibebankan kepadanya. Dengan termotivasinya dalam belajar-mengajar, bila dilaksanakan secara kontiniu akan menumbuhkan kemauan dan kerja keras pada diri peserta didik. Sehingga apabila disalurkan secara baik dapat dihubungkan dengan tujuannya untuk berprestasi.

Memperhatikan pengaruh yang diakibatkan dengan motivasi instrinsik menimbulkan kesan kiranya faktor ini dapat terus dikembangkan dalam usaha menumbuh dan mengembangkan motif peserta didik sesuai dengan potensi yang dimiliki. Menurut Yusuf (1987 : 83), "motivasi instrinsik merupakan sumber tenaga yang paling tahan lama,karena peserta didik merasa senang dan puas dalam belajar. Sehingga dalam pengelolaan proses belajar mengajar pendidik hendaknya dapat memperhatikan faktor-faktor yang tumbuh dari motivasi instrinsik seperti yang dimaksud dari pendapat tersebut".

Dengan memperhatikan pendapat di atas maka dapat dijelaskan bahwa motivasi merupakan dorongan dan rangsangan yang terjadi dalam diri individu yang diwujudkan kepada tingkah laku untuk memenuhi kebutuhan yang diinginkan. Dengan terwujudnya motivasi ke dalam bentuk tingkah laku,maka dapat diketahui dan diramalkan apa yang menjadi tujuan individu.

\section{Sarana dan Prasarana Terhadap Pembelajaran Penjaskes Di SD Negeri 22 Andalas Padang}

Sarana dan prasarana merupakan alat dan tempat terlaksananya suatu proses belajar mengajar dan merupakan salah satu aspek penunjang yang sangat penting di dalam pembinaan olahraga prestasi. Berdasarkan hasil penelitian Sarana dan prasarana terhadap pembelajaran Penjasorkes di SD Negeri 22 Andalas Padang diperoleh tingkatan capaian sebesar 60\%. Berada pada klarifikasi kurang baik. Dengan demikian artinya bahwa sarana dan prasarana dalam menunjang pembelajaran Penjasorkes di SD Negeri 22 Andalas Padang masih dikatakan kurang baik, namun masih perlu ditingkatkan sehingga pembelajaran penjasorkes dapat berjalan dengan lebih baik di masa yang akan datang.

Berdasarkan hal tersebut di atas, jelas bahwa tanpa adanya dukungan dari sarana dan prasarana yang memadai baik dari segi kuantitas maupun kualitas, hal ini berpengaruh terhadap kelancaran dalam proses pembelajaran. Sehingga dengan perlengkapan yang tidak mencukupi, maka pembelajaran tidak akan memuaskan. Jadi salah satu usaha untuk meraih hasil yang baik dalam olahraga saat ini akan ditentukan oleh sarana dan prasarana, baik dari segi jumlahnya maupun mutunya.

\section{Kesimpulan}

Berdasarkan hasil penelitian tentang Pembelajaran Penjasorkes di SD Negeri 22 Andalas Padang, maka dapat di ambil kesimpulan:

1. Kemampuan guru penjasorkes di SD Negeri 22 Andalas Padang pembelajaran penjasorkes sudah cukup baik, artinya kemampuan guru harus ditingkatkan lagi dalam pembelajaran penjas.

2. Motivasi siswa terhadap Pembelajaran Penjasorkes di SD Negeri 22 Andalas Padang 
sudah cukup baik, artinya motivasi siswa harus ditingkatkan lagi dalam pembelajaran penjas.

3. Sarana dan prasarana dalam menunjang pembelajaran Penjasorkes di SD Negeri 22 Andalas Padang masih dikatakan kurang baik, artinya Sarana dan prasarana harus ditingkatkan lagi dalam pembelajaran penjas.

\section{DAFTAR PUSTAKA}

Elida Prayitno (1989). Motivasi Belajar. Jakarta : P2LPTK.

Hadi, Sutrisno. (1993). Statistik Pendidikan II. Yogyakarta : Yayasan Penerbit Fakultas Psikologi UGM.

Harsuki. (2002). Perkembangan Olahraga Terkini. PT. Rajagrafindo Persada. Jakarta.

Lufri. (1999). Metode Penelitian. Jakarta : Rajawali.

Lutan, Rusli. (2001). Belajar Keterampilan Motorik, Pengantar Teori dan Metode. Jakarta. Departemen Pendidikan dan Kebudayaan.

M. Ngalim Purwanto. (1990) Psikologi Pendidikan. PT. Remaja Rosdakarya. Bandung.

Nana Sudjana. (1989). Metode Statistika (Edisi Ke-5). Bandung : Tarsito.

Ridwan. (2003). Metode Penelitian. Jakarta: Balai Pustaka.

Sarwono. (1983). Pengantar Umum Psikologi. Jakarta: Bulan Bintang.

Soemanto. (1990). Psikosslogi Pendidikan.Jakarta: Rineka Cipta.

Suharsimi Arikunto. (1989). Manajemen Penelitian. Jakarta: P2LPTK.

Undang-undang No. 20 Tahun 2003 Tentang Sistem Pendidikan Nasional. Jakarta: Diknas.

Undang-undang No. 3 Tahun 2005 Tentang Sistem Keolahragaan Nasional. Depdikbud.
Undang-undang No. 22 tahun 2006Tentang KTSP Peraturan Mentri.

UNP.(2008).Panduan Penulisan Skripsi. Padang. Depdiknas.

Wahjosumdjo. (2001). Kepemimpinan. Pusat Pendidikan dan Latihan Pegawai Depdikbud.

Winkel. (1984). Bimbingan dan Konseling di Lembaga Pendidikan. Gramedia. Jakarta.

Witherington. (1986). Teknik-teknik Belajar Mengajar. Bandung: Jammers.

Yanis,M. (1989). Sarana dan Prasarana. Padang: FPOK IKIP Padang.

Yusuf Adisasmita. (1989). Kepemimpinan. Jakarta: Pusat Pendidikan dan Latihan Pegawai Depdikbud.

Zalfendi,dkk. (2010) Analisa Kurikulum dalam Pembelajaran Penjas. Padang : Sukabima pers 